\title{
LOCAL ENVIRONMENTAL REGULATION AND PLANT-LEVEL PRODUCTIVITY
}

\author{
by \\ Randy A. Becker* \\ U.S. Bureau of the Census
}

CES 10-30 September, 2010

The research program of the Center for Economic Studies (CES) produces a wide range of economic analyses to improve the statistical programs of the U.S. Census Bureau. Many of these analyses take the form of CES research papers. The papers have not undergone the review accorded Census Bureau publications and no endorsement should be inferred. Any opinions and conclusions expressed herein are those of the author(s) and do not necessarily represent the views of the U.S. Census Bureau. All results have been reviewed to ensure that no confidential information is disclosed. Republication in whole or part must be cleared with the authors.

To obtain information about the series, see www.ces.census.gov or contact Cheryl Grim, Editor, Discussion Papers, U.S. Census Bureau, Center for Economic Studies 2K130B, 4600 Silver Hill Road, Washington, DC 20233, CES.Papers.List@census.gov. 


\begin{abstract}
This paper examines the impact of environmental regulation on the productivity of manufacturing plants in the United States. Establishment-level data from three Censuses of Manufactures are used to estimate 3-factor Cobb-Douglas production functions that include a measure of the stringency of environmental regulation faced by manufacturing plants. In contrast to previous studies, this paper examines effects on plants in all manufacturing industries, not just those in "dirty" industries. Further, this paper employs spatial-temporal variation in environmental compliance costs to identify effects, using a time-varying county-level index that is based on multiple years of establishment-level data from the Pollution Abatement Costs and Expenditures survey and the Annual Survey of Manufactures. Results suggest that, for the average manufacturing plant, the effect on productivity of being in a county with higher environmental compliance costs is relatively small and often not statistically significant. For the average plant, the main effect of environmental regulation may not be in the spatial and temporal dimensions.
\end{abstract}

Keywords: environmental regulation, productivity, U.S. manufacturing

* This paper has benefited from the helpful comments of Jim Davis, Lucia Foster, Wayne Gray, and participants at the Fourth World Congress of Environmental and Resource Economists. Any opinions and conclusions expressed herein are those of the author and do not necessarily represent the views of the U.S. Census Bureau. All results have been reviewed to ensure that no confidential information is disclosed. 


\section{Introduction}

This paper examines the impact of environmental regulation on the productivity of manufacturing plants in the United States. At the facility level, environmental regulation may affect productivity in at least two ways. First, compliance may require the diversion of inputs capital, labor, materials, etc. - toward the production of (unmeasured) environmental quality. Second, regulation may necessitate changes in the production process, reducing efficiency (as traditionally defined). At a more aggregate level, environmental regulation may affect productivity by exempting existing plants from the most stringent standards. This can discourage entry of new, more efficient producers.

A number of studies have attempted to measure the effects of environmental regulation on aggregate productivity (i.e., at the national, sectoral, or industry level), particularly on the productivity slowdown of the 1970s (see Jaffe et al. 1995 for a review). Gray (1987) examines productivity growth in 450 manufacturing industries (4-digit SIC industries) between 1958 and 1978 and finds that, for the average manufacturing industry, about $12 \%$ of the 1970 s productivity decline is attributable to environmental regulation - an estimate that does not achieve statistical significance. Barbera and McConnell (1986) focus on four particularly polluting (and regulated) manufacturing sectors (2- to 3-digit SIC industries) between 1960 and 1980 and find that pollution abatement requirements reduced both average labor productivity growth and capital productivity growth in the chemical and primary metal sectors, but not in paper. It further appears that environmental regulation is responsible for a large portion of the productivity slowdown after 1973. In another study, analyzing these same manufacturing sectors, the same authors find that environmental regulations reduced the productivity growth rate between $9 \%$ and $55 \%$, accounting for $10 \%$ to $30 \%$ of the 1970 s productivity decline (Barbera and McConnell 
1990).

A more limited number of studies have examined facility-level productivity, as I do here. For example, Gollop and Roberts (1983) find that electric utilities subject to greater restrictions on their sulfur dioxide emissions had lower productivity growth rates. Gray and Shadbegian (1995) find that $\$ 1$ of additional expenditure on pollution abatement reduced facility output by more than $\$ 1$ - upwards of $\$ 3.28$ for plants in the steel industry. In a more recent study, these same authors find that pollution abatement expenditure reduced productivity by $9.3 \%$ in “integrated" paper mills (i.e., ones that also produce pulp) and only $0.9 \%$ in non-integrated mills (Gray and Shadbegian 2003). In their study of integrated paper mills, Boyd and McClelland (1999) find a nearly identical reduction in productivity due to environmental constraints.

Meanwhile, Shadbegian and Gray (2005) find few statistically significant effects (positive or negative) of pollution abatement expenditures (capital, labor, or materials) on the productivity of paper mills, petroleum refineries, and steel plants.

In contrast to these other studies that also use facility-level data, I examine effects on plants in all manufacturing industries, not just those in "dirty" industries, such as electric utilities, steel, petroleum refining, and paper. Here, I employ establishment-level data from three Censuses of Manufactures (CMs) to estimate 3-factor Cobb-Douglas production functions. While these previous studies use a facility-specific measure of regulatory stringency, I employ spatialtemporal variation in environmental compliance costs, in the form of a newly developed countylevel index that reveals extra-normal environmental compliance costs, generally due to above- or below-normal environmental regulation and enforcement faced by manufacturers at the county level. This index is based on establishment-level data from multiple years of the Pollution Abatement Costs and Expenditures (PACE) survey and the Annual Survey of Manufactures 
(ASM).

Results suggest that, for the average manufacturing plant, the effect on productivity of being in a county with higher environmental compliance costs is relatively small - just a small fraction of $1 \%$ - and often not statistically significant. The paper proceeds as follows. Section 2 discusses the time-varying county-level index of environmental compliance costs, and Section 3 discusses the data and empirical specification used in the productivity analyses. Section 4 presents results, and Section 5 offers some concluding remarks.

\section{A Time-varying County-level Index of Environmental Compliance Costs}

In this paper, I use spatial and temporal variation in environmental compliance costs to examine the effects of environmental regulation on productivity. This variation is measured by a county-level index of the sort introduced and discussed in Becker (2011). In particular, I employ the establishment-level data from the PACE surveys of 1980-1982, 1984-1986, and 1988-1994, which includes data on total pollution abatement operating costs $(P A O C) .{ }^{1}$ PAOC includes salaries \& wages, parts \& materials, fuel \& electricity, capital depreciation, contract work, equipment leasing, and other operating costs associated with a plant's abatement of its air and water pollution as well as its solid waste in that calendar year. To this I merge data on these establishments from the ASM or CM, including employment, value of shipments, four-digit SIC industry, county, and plant vintage (as measured by an establishment's first appearance in the $\mathrm{CM})$. After restricting the sample to cases that had linkable PACE and ASM/CM records in a given year, and after eliminating inactive establishments, plants in Alaska and Hawaii, and those

\footnotetext{
${ }^{1}$ These survey data, as well as those from the Annual Survey of Manufactures and the Census of Manufactures, are confidential, collected and protected under Title 13 of the U.S. Code. Restricted access to these data can be arranged through the U.S. Census Bureau's Center for Economic Studies. See http://www.ces.census.gov/ for details.
} 
with missing or incomplete data on critical items, there are 188,326 establishment-years of observations for estimating the county-level index.

The basis for my index is an establishment's PAOC intensity — that is, its pollution abatement operating costs per unit of economic activity - namely, its value of shipments (VS). My county-level index of environmental compliance costs is the vector of $\phi_{m}$ parameters from the following regression equation:

$$
\ln \left(P^{\prime} A O C_{i} / V S_{i}\right)=\alpha+\beta \cdot \ln \left(\operatorname{median}_{j \in\left\{n^{\prime}, t^{\prime}, q^{\prime}\right\}}\left(\text { PAOC }_{j} / V S_{j}\right)\right)+\sum_{k \in K}\left(\gamma_{k} \cdot V_{k}\right)+\sum_{m \in M \otimes P}\left(\phi_{m} \cdot C_{m}\right)+\varepsilon_{i}
$$

where observation $i$ is an establishment in industry $n^{\prime}$, year $t^{\prime}$, size quartile $q^{\prime}$, and $j$ also indexes establishments in the sample. $K$ is the set of possible first CM appearances $\{1963,1967,1972$, $1977,1982,1987,1992,1997\}, k$ indexes those possibilities, and $V_{k}$ is one in a series of plant vintage indicators, less one omitted possibility (1963). $M$ is the set of U.S. counties, $P$ is the set of time periods used in estimation, $m$ indexes those county-periods, and $C_{m}$ is one in a series of county-period indicator variables, less one omitted category. In contrast to Becker (2011), where I estimate a county index for the entire time period, here I assume and employ three separate time periods: 1980-84, 1985-89, and 1990-94. As will become clearer in the next section, this creates index values that align with each of the three CMs used in the productivity estimation (namely, 1982, 1987, and 1992). Finally, the parameter $\alpha$ is the estimated constant, representing the omitted group (establishments in Washington DC in the period 1980-84 that were in existence as early as the $1963 \mathrm{CM}$ ), and $\varepsilon_{i}$ is an error term.

Since the value of the dependent variable is bounded from below for a significant number of observations, the parameters of equation (1) are estimated via a Tobit specification. ${ }^{2}$

\footnotetext{
${ }^{2}$ Establishments are asked to report their expenditures in thousands of dollars. Therefore, with rounding, a response of zero reflects expenditures of less than $\$ 500$. The cnreg (censored normal regression) command in Stata is a
} 
Furthermore, $\beta$ is restricted to be equal to one, forcing the notion that an establishment is expected to have PAOC intensity equivalent to the estimate for its industry-year-size class - in this case, the median. Deviations from this are, in part, explained by differences between counties, as measured by the estimated $\phi_{m}$ parameters - the county-level index. This index reveals any extra-normal environmental compliance costs, due to above- or below-normal environmental regulation and enforcement faced by manufacturers at the county level. The index also includes potential geographic differences in prices related to pollution abatement, such as the salaries of environmental workers, cost of low-sulfur coal, price of electricity, fees for solid waste hauling and disposal, and so forth. In the remainder of the paper, I will notate the index value of county $c$ in period $p$ as $E C C I N D E X_{c p}$.

This index's uniqueness prevents natural comparisons with other regulatory indexes. Nevertheless, the index is positively and significantly correlated with several state-level indexes produced by environmental organizations, including a +0.72 correlation with the state ranking based on the League of Conservation Voters (LCV) "scorecard" on each member of Congress. ${ }^{3}$ The only county-level comparison that can be made is to the (dichotomous) indicators of county non-attainment of the Clean Air Act's national ambient air quality standards (NAAQS) for each the six "criteria" air pollutants, which have been used by a number of researchers (this author included). I find that the index is positively and significantly correlated with NAAQS nonattainment statuses, but the correlation is relatively weak $(+0.12)$ and a regression reveals that

generalization of the standard Tobit procedure that allows the censoring point to vary by observation - in this case, $\ln \left(0.5 / V S_{i}\right)$.

${ }^{3}$ In particular, a regression is run of the county-period index on the complete set of state dummies, period dummies, and state-by-period dummies. The Spearman rank correlation between the resulting state coefficients and the states' ranking according to the LCV's National Environmental Scorecard for years 1977-1994 (as constructed by Levinson $2001)$ is +0.7240 . The county-level index is also highly correlated with the state-level FREE index $(+0.53)$ and the Hall-Kerr Green Index (+0.51), as republished in Levinson (2001). 
less than $2 \%$ of the variation can be explained by NAAQS non-attainment. ${ }^{4} \mathrm{~A}$ weak relationship is perhaps not unexpected since the index here captures expenditures on the abatement of air pollutants beside these six, as well as the abatement of water pollution and solid waste. Becker (2004) has also shown that certain populations can impact the pollution abatement expenditure of local manufacturers, over and above any "formal" regulatory requirements arising from county NAAQS non-attainment and from other state and federal regulation.

To provide a sense for this index and the cost differentials that are implied, I consider the difference between the 75 th and 25 th percentiles of its value. On average, all else being equal, plants located in the county with the higher index value would have pollution abatement operating costs that are about $198 \%$ higher. $^{5}$ According to data published by the U.S. Census Bureau, in 1992, there were approximately 370,900 manufacturing establishments, and they had approximately $\$ 17.5$ billion in PAOC, for an average of about $\$ 47,000$ per manufacturing establishment. $^{6}$ A $198 \%$ difference is roughly $\$ 93,000$, which, for the average manufacturing plant in 1992, was about $1.15 \%$ of its annual shipments (revenue) and $2.42 \%$ of its value added. Considering where manufacturing activity actually takes place, by weighting each county by its total manufacturing employment, all else equal, plants in the county at the 75th percentile would have pollution abatement operating costs that are about $65 \%$ higher than those for plants in the county at the 25 th percentile — a difference of about $\$ 30,500$ for the average manufacturing

\footnotetext{
${ }^{4}$ In particular, for 2,234 counties, I correlate the "1982" index value with the summation of non-attainment statuses within a county (nonattainment=1) across four different air pollutants (ozone, total suspended particulates, carbon monoxide, and sulfur dioxide) and five years (1980-1984). The regression is of the index value on a constant and the four different non-attainment statuses, where each is the summation of the respective non-attainment statuses over the five years 1980-1984. The R-squared from that regression is 0.0175 .

${ }^{5}$ There is uncertainty surrounding this difference, since index values toward the extremes tend to be less precisely estimated (i.e., tend to have higher standard errors, are based on fewer underlying observations). The precision of the index values is considered later in the paper.

${ }^{6}$ In actuality, the aggregate PAOC figure is for establishments with 20 or more employees, of which there were approximately 119,000 in 1992. Establishments with fewer than 20 employees tend to be in less-polluting industries and therefore have relatively small pollution abatement expenditure.
} 
plant in 1992 , or about $0.38 \%$ of its annual revenue and $0.79 \%$ of its value added. This of course hides significant industry heterogeneity. For example, the average pulp mill (SIC 2611) had roughly $\$ 6.5$ million of PAOC in 1992 - or about 138 times more than the average manufacturing plant. Moreover, a $65 \%$ difference was about $3.5 \%$ of the annual revenue for the average plant in this industry and $7.4 \%$ of its value added.

\section{Productivity Data and Empirical Specification}

Data to estimate plant-level productivity come from the CMs of 1982, 1987, and 1992, which include data on establishment employment, value of output, capital assets, material usage, location, industry, age, ownership, and so forth. After eliminating establishments that exhibited signs of inactivity (i.e., had a zero value for one or more critical items), whose data were largely imputed, and/or that were located in counties with no index, I am left with nearly 568,000 plantyears of observations.

To examine the effect of environmental compliance costs on manufacturer's productivity, I estimate some traditional Cobb-Douglas production functions. In particular, I estimate 3-factor Cobb-Douglas labor productivity regressions, one of which includes:

$$
\begin{aligned}
& \log \left(r V S_{i t} / E M P_{i t}\right)=\lambda_{0}+\lambda_{1} \cdot E_{C C I N D E X_{c p}}+\lambda_{2} \cdot \log \left(E_{i t}\right)+\lambda_{3} \cdot \log \left(\text { CAPITAL }_{i t} / \text { EMP }_{i t}\right)+ \\
& \lambda_{4} \cdot \log \left(r M A T_{i t} / E M P_{i t}\right)+\lambda_{5} \cdot \log \left(N P W E M P_{i t} / E M P_{i t}\right)+\lambda_{6} \cdot \text { MULTI }_{i t}+ \\
& \sum \lambda_{a} \cdot A G E_{\text {ait }}+\sum \lambda_{t} \cdot \mathrm{YEAR}_{t}+\sum \lambda_{n} \cdot \operatorname{SIC}_{n i t}+\sum \lambda_{c} \cdot \operatorname{COUNTY}_{c i}+e_{i t}
\end{aligned}
$$

where, for plant $i$ at time $t$ in county $c, r V S$ is output (the real value of shipments), EMP is the total number of employees, ECCINDEX is the time-varying county-level index of environmental compliance costs (as defined in the previous section), CAPITAL is the book value of capital assets, $r M A T$ is the real value of material inputs, $N P W E M P$ is the number of non-production workers (and $N P W E M P / E M P$ measures the proportion of the workforce that was not engaged in 
production - a commonly used measure of "skill" mix), MULTI is a dummy variable indicating a plant belonged to a multi-establishment firm, $A G E$ is a series of five categorical variables to designate the plant's age/vintage (less one omitted category), YEAR is a set of year dummies, SIC is a set of dummy variables indicating the plant's four-digit SIC industry, and COUNTY is a set of dummy variables indicating the plant's county. Industry-specific deflators, to create constant-dollar values for both value of shipments (VS) and value of material inputs (MAT), come from the NBER-CES Manufacturing Industry Database. ${ }^{7}$

Note that equation (2) controls for time-invariant location effects. This can be important if there are such fixed effects (observed or unobserved) that are correlated with both manufacturing plant productivity and the variable of interest, ECCINDEX. Indeed, ECCINDEX is found to have a statistically significant (positive) correlation with county characteristics such as total population, industrial concentration in manufacturing, and being in a metropolitan area, which may have impacts on plant productivity. An alternative specification that achieves the same goal substitutes county fixed effects with plant fixed effects $\left(P L A N T_{i}\right)$, as in:

$$
\begin{aligned}
\log \left(r V S_{i t} / E M P_{i t}\right)= & \lambda_{0}+\lambda_{1} \cdot E C C I N D E X_{c p}+\lambda_{2} \cdot \log \left(E M P_{i t}\right)+\lambda_{3} \cdot \log \left(C A P I T A L_{i t} / E M P_{i t}\right)+ \\
& \lambda_{4} \cdot \log \left(r M A T_{i t} / E M P_{i t}\right)+\lambda_{5} \cdot \log \left(N P W E M P_{i t} / E M P_{i t}\right)+\lambda_{6} \cdot \text { MULTI }_{i t}+ \\
& \sum \lambda_{a} \cdot A G E_{\text {ait }}+\sum \lambda_{t} \cdot Y E A R_{t}+\sum \lambda_{i} \cdot P L A N T_{i}+e_{i t}
\end{aligned}
$$

In addition to removing location specific effects, this specification obviously also controls for any time-invariant plant characteristics that play a role in productivity, as well as a degree of self-selection of plants into counties that may have higher or lower environmental regulation. Another difference in these two specifications is in the cases that contribute to the identification of $\lambda_{1}$. In (3), only plants that appear in at least two CMs help identify $\lambda_{1}$, while in (2), a plant contributes to the identification of $\lambda_{1}$ as long as its county appears in at least two CMs. Since

\footnotetext{
${ }^{7}$ The latest version of this database is available at http://www.nber.org/data/nbprod2005.html.
} 
plants change industries relatively infrequently, industry fixed effects are excluded from equation

(3). In the next section, I present results from both of these specifications, and variations thereof.

\section{Results}

Table 1 presents results from county fixed effect models, a la equation (2), and Table 2 presents results from plant fixed effects models, a la equation (3). Column (1) in each table contains results from the simplest labor productivity equations, without $E C C I N D E X$ or the supplemental plant characteristics, while column (2) adds our variable of interest, ECCINDEX. Column (3) of each table contains results from the (full) models specified in equations (2) and (3), respectively, adding three plant characteristics commonly thought to have potential impacts on productivity (NPWEMP/EMP, MULTI, and $A G E$ ). Finally, column (4) also includes timevarying county-level manufacturing employment, as calculated with these same CM data. This variable measures changing "economies of agglomeration" as manufacturing activity increases or declines in a county. Such a measure also proxies for any observable and unobservable characteristics of a county that (i) vary over time, (ii) contribute to productivity, and (iii) lead manufacturers to increase or decrease their activity there.

In none of the specifications of Table 1 or Table 2 does ECCINDEX have a statistically significant effect on productivity. Table 3 evaluates the robustness of these results, employing several alternate samples. Sample 2 includes plants, previously excluded, whose data were largely imputed. Sample 3 eliminates establishments in the top and bottom $1 \%$ of ECCINDEX, to assess whether extreme cases are influencing results. Neither of these samples changes the basic conclusion, though in the latter case, the point estimates do change a fair amount, but are nonetheless statistically insignificant. Endogeneity may be a concern in these analyses, since 
plants in the productivity regressions may also be in the sample used to estimate ECCINDEX.

Sample 4 treats this by excluding all plants that entered the estimation of (contemporaneous)

ECCINDEX. The point estimates are a bit higher but statistically insignificant. Sample 4 is rather unforgiving - eliminating $13.3 \%$ of the sample (relative to Sample 1), including many “important" plants, as well as ones located in counties with extensive manufacturing activity, where a single plant has little likelihood of dominating the estimated ECCINDEX. Sample 5 instead eliminates plants that entered the estimation of ECCINDEX, but only if the plant contributed at least $20 \%$ of the underlying observations in that county-period. ${ }^{8}$ Again, ECCINDEX has no statistically significant effect on productivity. Meanwhile, the coefficients on the models' other variables are as one might expect. ${ }^{9}$

These results suggest that the average manufacturing plant does not have lower productivity in counties with higher environmental compliance costs. One possible issue with these specifications is that the effect of ECCINDEX is identified only by changes within a county, for counties or plants that appear more than once. If much of the variation in ECCINDEX is cross-sectional (i.e., across counties, rather than over time), and if there is measurement error in ECCINDEX (and the estimation of equation (1) does yield a standard error on each index value), then controlling for county or plant fixed effects may leave relatively little "true" variation in ECCINDEX, which may bias its coefficient toward zero. Indeed, I find that of the 2,059 counties with an ECCINDEX for both the period 1980-84 and 1990-94, only 206

\footnotetext{
${ }^{8}$ Cutoffs of $10 \%$ and $5 \%$ were also chosen, yielding the same essential conclusion.

${ }^{9}$ A labor productivity equation in the form of $(Q / L)=A \cdot L^{\alpha+\beta+\gamma-1}(K / L)^{\beta}(M / L)^{\gamma}$ is derived from a standard CobbDouglas production function of the form $Q=A \cdot L^{\alpha} K^{\beta} M^{\prime}$. The coefficient on $\log (E M P)$, therefore, is $\alpha+\beta+\gamma-1$. Therefore, column 4 of Table 1 [2] shows output elasticities on labor, capital, and materials of $0.385,0.162$, and 0.446 , [0.459, 0.097, and 0.346], respectively, with statistically significant decreasing returns to scale in both instances. Meanwhile, the skill measure and multi-establishment status are both found to have statistically significant positive effects on labor productivity, and county manufacturing employment also has a statistically significant positive effect, as expected.
} 
experienced a statistically meaningful change between those two periods. ${ }^{10,11}$ With this in mind, I present results from two further exercises.

First, I re-estimate the models of Tables 1 and 2, using only those plants in counties with statistically meaningful changes in their ECCINDEX. ${ }^{12}$ The results are presented in Tables 4 and 5, respectively. In the county fixed effect models (Table 4), ECCINDEX has a statistically significant (negative) effect on productivity, until county-level manufacturing employment is added to the specification in column 4. In the plant fixed effect models (Table 5), ECCINDEX has a statistically significant (negative) effect in all specifications. ${ }^{13}$ To help interpret these coefficients, I compute the effect on labor productivity for the plant experiencing the average change in ECCINDEX, among those plants contributing to the identification of the coefficient in these two sets of regressions. In the county fixed effect regressions, the average plant experienced an increase in ECCINDEX between its first and last year of appearance that translates to a decrease in labor productivity between $-0.08 \%$ and $-0.11 \%$. In the plant effect

\footnotetext{
${ }^{10}$ In particular, I test whether the $90 \%$ confidence interval of the difference in the index values excludes zero. The formula $\left(E C \widehat{C I N D} E X_{c^{\prime} 1992}-E C \widehat{C I N D} E X_{c^{\prime} 1982}\right) \pm 1.645 \cdot\left(\widehat{s e}_{c^{\prime} 1982}^{2}+\widehat{s e}_{c^{\prime} 1992}^{2}\right)^{1 / 2}$ allows some overlap of the confidence intervals of the two individual index values (Schenker and Gentleman 2001).

${ }^{11}$ No major manufacturing counties are among these 206 , and collectively they contain less than $3 \%$ of U.S. manufacturing employment. An alternate specification of ECCINDEX yields a similar result. Namely, specification \#6 in Becker (2011) uses: (i) plant employment (EMP) in the denominator of PAOC intensity (and expected PAOC intensity), instead of value of shipments (VS), and (ii) the weighted mean in computing expected PAOC intensity, instead of median. With this index, I find that 256 counties - containing $4 \%$ of U.S. manufacturing employment experienced a statistically meaningful change between those two periods.

${ }^{12}$ In particular, for each county, I perform pairwise tests between the index values in $1982 \& 1987,1987 \& 1992$, and $1982 \& 1992$. If there are no statistically meaningful differences between any of the three pairs, the county and all of its plants are dropped from the sample. If only one statistically meaningful difference is found (e.g., between $1982 \&$ 1992), then only observations in the remaining year are dropped (in this example, 1987). If two statistically meaningfully differences are found (e.g., between 1982 \& 1992 and 1987 \& 1992), all years and observations are retained.

${ }^{13}$ The endogeneity issue discussed above may be more of a concern here, since the counties in this sample appear to have less manufacturing activity than average and therefore a particular plant may be more likely to dominate the estimated ECCINDEX. Re-estimating the models of Table 4 and 5, using a sample that - like Sample 5 above eliminates plants that entered the estimation of ECCINDEX but only if the plant contributed at least $20 \%$ of the underlying observations in that county-period ( $\mathrm{N}=14,993)$, yields negative coefficients on ECCINDEX that are $50 \%$ to $75 \%$ the magnitude of those in Tables 4 and 5, and that do not quite achieve statistical significance. Unrelated to this, using the alternate specification of ECCINDEX, discussed in a footnote above, also does not yield a statistically significant coefficient in any of the regressions of Tables 4 or 5 , or in the regressions of Table 6.
} 
regressions, the average plant experienced a decrease in labor productivity between $-0.10 \%$ and $-0.11 \%$. These seem relatively small effects.

Second, I estimate versions of equation (2) that employ 179 BEA economic area fixed effects (Johnson and Kort 2004) instead of county fixed effects. This allows for some crosssectional variation in $E C C I N D E X$ while still controlling for local unobservables to a certain degree. Results appear in Table 6. We see that the effect of ECCINDEX is not statistically significant, though it is nearly so $(\mathrm{p}=0.118)$ in column (4). To help interpret this particular point estimate, I compute the effect on labor productivity of moving from the 25 th percentile of ECCINDEX in this sample to the 75 th percentile, holding all other variables constant. The effect of such an increase in the index is a decrease in labor productivity of about $-0.04 \%$. Again, a relatively small effect.

\section{Conclusion}

This paper has explored the impact of environmental regulation on the productivity of manufacturing plants in the United States. In contrast to previous studies that have also used establishment-level data, I examine effects on plants in all manufacturing industries, not just those in "dirty" industries. Further, I employ spatial and temporal variation in environmental compliance costs to identify effects.

The results here suggest that, for the average manufacturing plant, the effect on productivity of being in a county with higher environmental compliance costs is relatively small. Even when focusing just on counties with "meaningful" temporal variation in ECCINDEX, or by allowing for some cross-sectional variation through the use of BEA economic area fixed effects, ECCINDEX decreases labor productivity for the average plant by just a small fraction of $1 \%$ - an 
effect that does not often achieve statistical significance. Compare this to Figure 1, which suggests that the manufacturing sector as a whole expended about $1.0 \%$ to $1.3 \%$ of its value added on pollution abatement operating costs during this period, according to published statistics.

The results in this paper do not necessarily suggest that environmental regulation has little impact on productivity. Rather, it appears that whatever spatial and temporal variation exists (as embodied in this particular index) has little effect on productivity, at least for the average manufacturing plant. Spatial competition may still be a major issue for plants in particularly polluting industries (see Becker and Henderson 2000, Greenstone 2002, Becker 2005). For the average plant however, the main effect of environmental regulation may not be in the spatial and temporal dimensions. The (non-)result here in this paper is consistent with Gray (1987), which found no statistically significant effect of pollution abatement spending on the productivity of the average manufacturing industry, during the period leading up to that explored here in this study.

In future work, I hope to explore outcomes besides productivity. For example, with this index, one could begin to (re-)explore the effects of environmental regulation on industrial location, employment, investment (including foreign direct investment), industrial emissions, ambient pollution levels, and so forth, using U.S. counties as the laboratory, rather than - the more usual - states. This paper has shown that there may not be a sufficient number of observations in the PACE data to support the estimation of a time-varying county-level index. In particular, the precision of the resulting time-varying ECCINDEX simply is not great enough to discern many statistically meaningful changes over time in county-level environmental compliance costs, even if such changes were real. This is true even with the pooling of multiple years into a county-period index. This suggests that the index's best use may be as a time- 
invariant index, as presented in Becker (2011). 


\section{References}

Barbera, Anthony J. and Virginia D. McConnell. "The Impact of Environmental Regulations on Industry Productivity: Direct and Indirect Effects," Journal of Environmental Economics and Management, 18(1), 50-65, January 1990.

Barbera, Anthony J. and Virginia D. McConnell. "Effects of Pollution Control on Industry Productivity: A Factor Demand Approach," Journal of Industrial Economics, 35(2), 161172, December 1986.

Becker, Randy A. "On Spatial Heterogeneity in Environmental Compliance Costs," Land Economics, 87(1), forthcoming (2011). (Available as: Center for Economic Studies Discussion Paper, 09-25R, January 2010.)

Becker, Randy A. "Air Pollution Abatement Costs under the Clean Air Act: Evidence from the PACE Survey," Journal of Environmental Economics and Management, 50(1), 144-169, July 2005.

Becker, Randy A. "Pollution Abatement Expenditures by U.S. Manufacturing Plants: Do Community Characteristics Matter?" Contributions to Economic Analysis \& Policy, 3(2), Article 6, December 2004.

Becker, Randy A. and Vernon Henderson. "Effects of Air Quality Regulations on Polluting Industries," Journal of Political Economy, 108(2), 379-421, April 2000.

Boyd, Gale A. and John D. McClelland. "The Impact of Environmental Constraints on Productivity Improvement in Integrated Paper Plants," Journal of Environmental Economics and Management, 38(2), 121-142, September 1999.

Gollop, Frank M. and Mark J. Roberts. "Environmental Regulations and Productivity Growth: The Case of Fossil-fueled Electric Power Generation," Journal of Political Economy, 91(4), 654-674, August 1983.

Gray, Wayne B. "The Cost of Regulation: OSHA, EPA and the Productivity Slowdown," American Economic Review, 77(5), 998-1006, December 1987.

Gray, Wayne B. and Ronald J. Shadbegian. "Pollution Abatement Costs, Regulation, and PlantLevel Productivity,” NBER Working Paper Series, 4994, January 1995.

Gray, Wayne B. and Ronald J. Shadbegian. "Plant Vintage, Technology, and Environmental Regulation," Journal of Environmental Economics and Management, 46(3), 384-402, November 2003.

Greenstone, Michael. "The Impacts of Environmental Regulations on Industrial Activity: Evidence from the 1970 and 1977 Clean Air Act Amendments and the Census of Manufactures," Journal of Political Economy, 110(6), 1175-1219, December 2002. 
Jaffe, Adam B., Steven R. Peterson, Paul R. Portney, and Robert N. Stavins. "Environmental Regulations and the Competitiveness of U.S. Manufacturing: What Does the Evidence Tell Us?" Journal of Economic Literature, 33(1), 132-163, March 1995.

Johnson, Kenneth P. and John R. Kort. "2004 Redefinition of the BEA Economic Areas," Survey of Current Business, 84(11), 69-75, November 2004.

Levinson, Arik. "An Industry-adjusted Index of State Environmental Compliance Costs," in Behavioral and Distributional Effects of Environmental Policy, Carlo Carraro and Gilbert E. Metcalf (eds.), National Bureau of Economic Research and The University of Chicago Press, 2001.

Schenker, Nathaniel, and Jane F. Gentleman. "On Judging the Significance of Differences by Examining the Overlap Between Confidence Intervals," The American Statistician, 55(3), 182-186, August 2001.

Shadbegian, Ronald J. and Wayne B. Gray. "Pollution Abatement Expenditures and Plant-level Productivity: A Production Function Approach,” Ecological Economics, 54(2-3), 196-208, August 2005.

U.S. Bureau of the Census. Pollution Abatement Costs and Expenditures, 19_. Washington, DC: U.S. Government Printing Office, various years. 


\section{TABLE 1}

Cobb-Douglas Labor Productivity Regressions with County Fixed Effects ${ }^{\dagger}$

\begin{tabular}{|c|c|c|c|c|}
\hline & $(1)$ & (2) & (3) & (4) \\
\hline County-level environmental compliance cost index & & $\begin{array}{l}-0.0002 \\
(0.0007)\end{array}$ & $\begin{array}{l}-0.0001 \\
(0.0007)\end{array}$ & $\begin{array}{l}-0.0000 \\
(0.0007)\end{array}$ \\
\hline County-level manufacturing employment & & & & $\begin{array}{l}+0.0199 * * * \\
(0.0037)\end{array}$ \\
\hline Employees & $\begin{array}{l}+0.0095 * * * \\
(0.0005)\end{array}$ & $\begin{array}{l}+0.0095 * * * \\
(0.0005)\end{array}$ & $\begin{array}{l}-0.0080^{* * *} \\
(0.0005)\end{array}$ & $\begin{array}{l}-0.0080^{* * *} \\
(0.0005)\end{array}$ \\
\hline Capital assets per employee & $\begin{array}{l}+0.1688^{* * *} \\
(0.0010)\end{array}$ & $\begin{array}{l}+0.1688^{* * *} \\
(0.0010)\end{array}$ & $\begin{array}{l}+0.1618^{* * *} \\
(0.0010)\end{array}$ & $\begin{array}{l}+0.1618^{* * *} \\
(0.0010)\end{array}$ \\
\hline Materials per employee & $\begin{array}{l}+0.4520^{* * *} \\
(0.0012)\end{array}$ & $\begin{array}{l}+0.4520^{* * *} \\
(0.0012)\end{array}$ & $\begin{array}{l}+0.4455^{* * *} \\
(0.0012)\end{array}$ & $\begin{array}{l}+0.4455^{* * *} \\
(0.0012)\end{array}$ \\
\hline Non-production workers per employee & & & $\begin{array}{l}+0.1357^{* * *} \\
(0.0039)\end{array}$ & $\begin{array}{l}+0.1358^{* * *} \\
(0.0039)\end{array}$ \\
\hline Multi-establishment firm & & & $\begin{array}{l}+0.1089^{* * *} \\
(0.0015)\end{array}$ & $\begin{array}{l}+0.1089 * * * \\
(0.0015)\end{array}$ \\
\hline 1987 & $\begin{array}{l}+0.0583^{* * *} \\
(0.0012)\end{array}$ & $\begin{array}{l}+0.0583 * * * \\
(0.0012)\end{array}$ & $\begin{array}{l}+0.0585^{* * *} \\
(0.0012)\end{array}$ & $\begin{array}{l}+0.0587 * * * \\
(0.0012)\end{array}$ \\
\hline 1992 & $\begin{array}{l}-0.0399 * * * \\
(0.0013)\end{array}$ & $\begin{array}{l}-0.0399 * * * \\
(0.0013)\end{array}$ & $\begin{array}{l}-0.0385^{* * *} \\
(0.0013)\end{array}$ & $\begin{array}{l}-0.0371 * * * \\
(0.0013)\end{array}$ \\
\hline Plant age categories & no & no & yes & yes \\
\hline Four-digit SIC industry effects & yes & yes & yes & yes \\
\hline County effects & yes & yes & yes & yes \\
\hline R-squared & 0.7852 & 0.7852 & 0.7892 & 0.7892 \\
\hline Number of observations & 567,753 & 567,753 & 567,753 & 567,753 \\
\hline
\end{tabular}


TABLE 2

Cobb-Douglas Labor Productivity Regressions with Plant Fixed Effects ${ }^{\dagger}$

\begin{tabular}{|c|c|c|c|c|}
\hline & $(1)$ & $(2)$ & (3) & (4) \\
\hline County-level environmental compliance cost index & & $\begin{array}{c}-0.0002 \\
(0.0007)\end{array}$ & $\begin{array}{c}-0.0004 \\
(0.0007)\end{array}$ & $\begin{array}{c}-0.0004 \\
(0.0007)\end{array}$ \\
\hline County-level manufacturing employment & & & & $\begin{array}{l}+0.0095 * * * \\
(0.0019)\end{array}$ \\
\hline Employees & $\begin{array}{l}-0.0889^{* * *} \\
(0.0013)\end{array}$ & $\begin{array}{c}-0.0889^{* * *} \\
(0.0013)\end{array}$ & $\begin{array}{c}-0.0978^{* * *} \\
(0.0013)\end{array}$ & $\begin{array}{l}-0.0980^{* * *} \\
(0.0013)\end{array}$ \\
\hline Capital assets per employee & $\begin{array}{c}+0.0975^{* * *} \\
(0.0009)\end{array}$ & $\begin{array}{c}+0.0975^{* * *} \\
(0.0009)\end{array}$ & $\begin{array}{l}+0.0971^{* * *} \\
(0.0009)\end{array}$ & $\begin{array}{l}+0.0971 \text { *** } \\
(0.0009)\end{array}$ \\
\hline Materials per employee & $\begin{array}{c}+0.3463 * * * \\
(0.0010)\end{array}$ & $\begin{array}{c}+0.3463^{* * * *} \\
(0.0010)\end{array}$ & $\begin{array}{c}+0.3462^{* * * *} \\
(0.0010)\end{array}$ & $\begin{array}{l}+0.3462 * * * \\
(0.0010)\end{array}$ \\
\hline Non-production workers per employee & & & $\begin{array}{c}+0.0172^{* * *} \\
(0.0045)\end{array}$ & $\begin{array}{l}+0.0175^{* * *} \\
(0.0045)\end{array}$ \\
\hline Multi-establishment firm & & & $\begin{array}{c}+0.0172^{* * *} \\
(0.0045)\end{array}$ & $\begin{array}{l}+0.0288^{* * *} \\
(0.0037)\end{array}$ \\
\hline 1987 & $\begin{array}{c}+0.0911^{* * *} \\
(0.0012)\end{array}$ & $\begin{array}{c}+0.0911^{* * *} \\
(0.0012)\end{array}$ & $\begin{array}{c}+0.0712^{* * *} \\
(0.0015)\end{array}$ & $\begin{array}{l}+0.0715^{* * *} \\
(0.0015)\end{array}$ \\
\hline 1992 & $\begin{array}{c}+0.0233^{* * *} \\
(0.0014)\end{array}$ & $\begin{array}{c}+0.0233^{* * *} \\
(0.0014)\end{array}$ & $\begin{array}{l}-0.0200^{* * *} \\
(0.0022)\end{array}$ & $\begin{array}{l}-0.0188^{* * *} \\
(0.0022)\end{array}$ \\
\hline Plant age categories & no & no & yes & yes \\
\hline Plant effects & yes & yes & yes & yes \\
\hline R-squared & 0.9435 & 0.9435 & 0.9438 & 0.9438 \\
\hline Number of observations & 567,753 & 567,753 & 567,753 & 567,753 \\
\hline
\end{tabular}

$\bar{\dagger}$ The dependent variable is real value of shipments per employee. This variable, the three factors of production, and county-level manufacturing employment are in natural logs. Statistical significance at the $10 \%, 5 \%$, and $1 \%$ level are indicated by single, double, and triple asterisks, respectively. 
TABLE 3

Coefficient on ECCINDEX:

Alternate Samples ${ }^{\dagger}$

1. From column 4 of Tables 1 and 2 , respectively

2. Include plants whose data were largely imputed

3. Exclude observations with most extreme values of ECCINDEX (top and bottom 1 percent)
County fixed Plant fixed effect model

eff
Number of observations

$\begin{array}{ccc}-0.0000 & -0.0004 & 567,753 \\ (0.0007) & (0.0007) & \\ +0.0001 & +0.0001 & 941,503 \\ (0.0004) & (0.0005) & \\ +0.0023 & -0.0018 & 556,397 \\ (0.0017) & (0.0018) & \\ +0.0003 & +0.0003 & 492,252 \\ (0.0007) & (0.0009) & \\ -0.0001 & -0.0003 & 560,613 \\ (0.0007) & (0.0008) & \end{array}$
(0.0008)

4. Exclude all plants that entered the estimation of contemporaneous +0.0003 ECCINDEX

5. Exclude plants that entered the estimation of contemporaneous ECCINDEX, unless the plant contributed $<20 \%$ of observations

\footnotetext{
$\bar{\dagger}$ This table contains coefficients on county-level environmental compliance cost index (ECCINDEX) from empirical specifications identical to those in column (4) of Tables 1 and 2. Statistical significance at the 10\%, 5\%, and 1\% level are indicated by single, double, and triple asterisks, respectively.
} 
TABLE 4

Cobb-Douglas Labor Productivity Regressions with County Fixed Effects: Sample Restricted to Counties with "Meaningful" Changes ${ }^{\dagger}$

\begin{tabular}{|c|c|c|c|c|}
\hline & $(1)$ & $(2)$ & (3) & $(4)$ \\
\hline County-level environmental compliance cost index & & $\begin{array}{c}-0.0041^{*} \\
(0.0023)\end{array}$ & $\begin{array}{c}-0.0039^{*} \\
(0.0023)\end{array}$ & $\begin{array}{c}-0.0030 \\
(0.0023)\end{array}$ \\
\hline County-level manufacturing employment & & & & $\begin{array}{c}+0.0703 * * * \\
(0.0183)\end{array}$ \\
\hline Employees & $\begin{array}{c}+0.0083^{* * *} \\
(0.0029)\end{array}$ & $\begin{array}{l}+0.0082 * * * \\
(0.0029)\end{array}$ & $\begin{array}{l}-0.0090^{* * *} \\
(0.0033)\end{array}$ & $\begin{array}{c}-0.0095^{* * *} \\
(0.0033)\end{array}$ \\
\hline Capital assets per employee & $\begin{array}{c}+0.1734 * * * \\
(0.0058)\end{array}$ & $\begin{array}{c}+0.1735^{* * *} \\
(0.0058)\end{array}$ & $\begin{array}{c}+0.1660^{* * *} \\
(0.0057)\end{array}$ & $\begin{array}{c}+0.1662 * * * \\
(0.0057)\end{array}$ \\
\hline Materials per employee & $\begin{array}{c}+0.4486^{* * *} \\
(0.0074)\end{array}$ & $\begin{array}{c}+0.4485^{* * *} \\
(0.0074)\end{array}$ & $\begin{array}{c}+0.4428^{* * *} \\
(0.0074)\end{array}$ & $\begin{array}{c}+0.4426^{* * *} \\
(0.0074)\end{array}$ \\
\hline Non-production workers per employee & & & $\begin{array}{c}+0.0830 * * * \\
(0.0241)\end{array}$ & $\begin{array}{l}+0.0831 * * * \\
(0.0240)\end{array}$ \\
\hline Multi-establishment firm & & & $\begin{array}{c}+0.1158^{* * *} \\
(0.0089)\end{array}$ & $\begin{array}{c}+0.1160^{* * *} \\
(0.0089)\end{array}$ \\
\hline 1987 & $\begin{array}{l}+0.0404 * * * \\
(0.0082)\end{array}$ & $\begin{array}{l}+0.0432 * * * \\
(0.0082)\end{array}$ & $\begin{array}{c}+0.0454^{* * *} \\
(0.0082)\end{array}$ & $\begin{array}{c}+0.0370^{* * *} \\
(0.0084)\end{array}$ \\
\hline 1992 & $\begin{array}{l}-0.0515^{* * *} \\
(0.0079)\end{array}$ & $\begin{array}{l}-0.0500 * * * \\
(0.0079)\end{array}$ & $\begin{array}{c}-0.0469^{* * *} \\
(0.0080)\end{array}$ & $\begin{array}{c}-0.0552 * * * \\
(0.0083)\end{array}$ \\
\hline Plant age categories & no & no & yes & yes \\
\hline Four-digit SIC industry effects & yes & yes & yes & yes \\
\hline County effects & yes & yes & yes & yes \\
\hline R-squared & 0.7972 & 0.7972 & 0.8006 & 0.8008 \\
\hline Number of observations & 16,042 & 16,042 & 16,042 & 16,042 \\
\hline
\end{tabular}


TABLE 5

Cobb-Douglas Labor Productivity Regressions with Plant Fixed Effects: Sample Restricted to Counties with "Meaningful" Changes ${ }^{\dagger}$

\begin{tabular}{|c|c|c|c|c|}
\hline & $(1)$ & $(2)$ & (3) & (4) \\
\hline County-level environmental compliance cost index & & $\begin{array}{l}-0.0059^{* *} \\
(0.0026)\end{array}$ & $\begin{array}{l}-0.0060^{* *} \\
(0.0026)\end{array}$ & $\begin{array}{l}-0.0052^{* *} \\
(0.0026)\end{array}$ \\
\hline County-level manufacturing employment & & & & $\begin{array}{c}+0.0676^{* * *} \\
(0.0200)\end{array}$ \\
\hline Employees & $\begin{array}{l}-0.0963 * * * \\
(0.0093)\end{array}$ & $\begin{array}{l}-0.0970 * * * \\
(0.0093)\end{array}$ & $\begin{array}{l}-0.1000 * * * \\
(0.0095)\end{array}$ & $\begin{array}{c}-0.1039 * * * \\
(0.0095)\end{array}$ \\
\hline Capital assets per employee & $\begin{array}{c}+0.1098^{* * *} \\
(0.0063)\end{array}$ & $\begin{array}{c}+0.1100^{* * *} \\
(0.0063)\end{array}$ & $\begin{array}{c}+0.1096^{* * *} \\
(0.0063)\end{array}$ & $\begin{array}{c}+0.1096 * * * \\
(0.0063)\end{array}$ \\
\hline Materials per employee & $\begin{array}{c}+0.3384^{* * * *} \\
(0.0066)\end{array}$ & $\begin{array}{c}+0.3382^{* * * *} \\
(0.0066)\end{array}$ & $\begin{array}{c}+0.3382 * * * \\
(0.0066)\end{array}$ & $\begin{array}{c}+0.3378^{* * *} \\
(0.0066)\end{array}$ \\
\hline Non-production workers per employee & & & $\begin{array}{c}-0.0291 \\
(0.0318)\end{array}$ & $\begin{array}{c}-0.0292 \\
(0.0317)\end{array}$ \\
\hline Multi-establishment firm & & & $\begin{array}{c}-0.0222 \\
(0.0272)\end{array}$ & $\begin{array}{c}-0.0225 \\
(0.0272)\end{array}$ \\
\hline 1987 & $\begin{array}{c}+0.0798 * * * \\
(0.0090)\end{array}$ & $\begin{array}{l}+0.0838^{* * *} \\
(0.0092)\end{array}$ & $\begin{array}{c}+0.0799 * * * \\
(0.0109)\end{array}$ & $\begin{array}{c}+0.0728^{* * *} \\
(0.0111)\end{array}$ \\
\hline 1992 & $\begin{array}{c}+0.0132 \\
(0.0096)\end{array}$ & $\begin{array}{c}+0.0152 \\
(0.0096)\end{array}$ & $\begin{array}{c}+0.0068 \\
(0.0157)\end{array}$ & $\begin{array}{c}+0.0002 \\
(0.0158)\end{array}$ \\
\hline Plant age categories & no & no & yes & yes \\
\hline Plant effects & yes & yes & yes & yes \\
\hline R-squared & 0.9568 & 0.9568 & 0.9569 & 0.9570 \\
\hline Number of observations & 16,042 & 16,042 & 16,042 & 16,042 \\
\hline
\end{tabular}




\section{TABLE 6}

Cobb-Douglas Labor Productivity Regressions with BEA Economic Area Fixed Effects ${ }^{\dagger}$

\begin{tabular}{|c|c|c|c|c|}
\hline & $(1)$ & $(2)$ & (3) & $(4)$ \\
\hline County-level environmental compliance cost index & & $\begin{array}{c}-0.0005 \\
(0.0006)\end{array}$ & $\begin{array}{c}-0.0003 \\
(0.0005)\end{array}$ & $\begin{array}{c}-0.0009 \\
(0.0005)\end{array}$ \\
\hline County-level manufacturing employment & & & & $\begin{array}{l}+0.0158^{* * *} \\
(0.0005)\end{array}$ \\
\hline Employees & $\begin{array}{l}+0.0087 * * * \\
(0.0005)\end{array}$ & $\begin{array}{l}+0.0087 * * * \\
(0.0005)\end{array}$ & $\begin{array}{l}-0.0087 * * * \\
(0.0005)\end{array}$ & $\begin{array}{l}-0.0085^{* * *} \\
(0.0005)\end{array}$ \\
\hline Capital assets per employee & $\begin{array}{c}+0.1690 * * * \\
(0.0010)\end{array}$ & $\begin{array}{c}+0.1690^{* * *} \\
(0.0010)\end{array}$ & $\begin{array}{l}+0.1620 * * * \\
(0.0010)\end{array}$ & $\begin{array}{c}+0.1623 * * * \\
(0.0010)\end{array}$ \\
\hline Materials per employee & $\begin{array}{l}+0.4544 * * * \\
(0.0012)\end{array}$ & $\begin{array}{l}+0.4544 * * * \\
(0.0012)\end{array}$ & $\begin{array}{l}+0.4478 * * * \\
(0.0012)\end{array}$ & $\begin{array}{c}+0.4470 * * * \\
(0.0012)\end{array}$ \\
\hline Non-production workers per employee & & & $\begin{array}{l}+0.1458^{* * *} \\
(0.0039)\end{array}$ & $\begin{array}{c}+0.1409^{* * *} \\
(0.0039)\end{array}$ \\
\hline Multi-establishment firm & & & $\begin{array}{c}+0.1067^{* * *} \\
(0.0015)\end{array}$ & $\begin{array}{c}+0.1087^{* * *} \\
(0.0015)\end{array}$ \\
\hline 1987 & $\begin{array}{c}+0.0574 * * * \\
(0.0012)\end{array}$ & $\begin{array}{c}+0.0575^{* * *} \\
(0.0012)\end{array}$ & $\begin{array}{c}+0.0575^{* * *} \\
(0.0012)\end{array}$ & $\begin{array}{c}+0.0585^{* * *} \\
(0.0012)\end{array}$ \\
\hline 1992 & $\begin{array}{c}-0.0424 * * * \\
(0.0013)\end{array}$ & $\begin{array}{c}-0.0424 * * * \\
(0.0013)\end{array}$ & $\begin{array}{l}-0.0414 * * * \\
(0.0013)\end{array}$ & $\begin{array}{l}-0.0384 * * * \\
(0.0013)\end{array}$ \\
\hline Plant age categories & no & no & yes & yes \\
\hline Four-digit SIC industry effects & yes & yes & yes & yes \\
\hline BEA economic area effects & yes & yes & yes & yes \\
\hline R-squared & 0.7830 & 0.7830 & 0.7870 & 0.7875 \\
\hline Number of observations & 567,753 & 567,753 & 567,753 & 567,753 \\
\hline
\end{tabular}


FIGURE 1

Ratio of Pollution Abatement Operating Costs to Value Added in the U.S. Manufacturing Sector ${ }^{\dagger}$

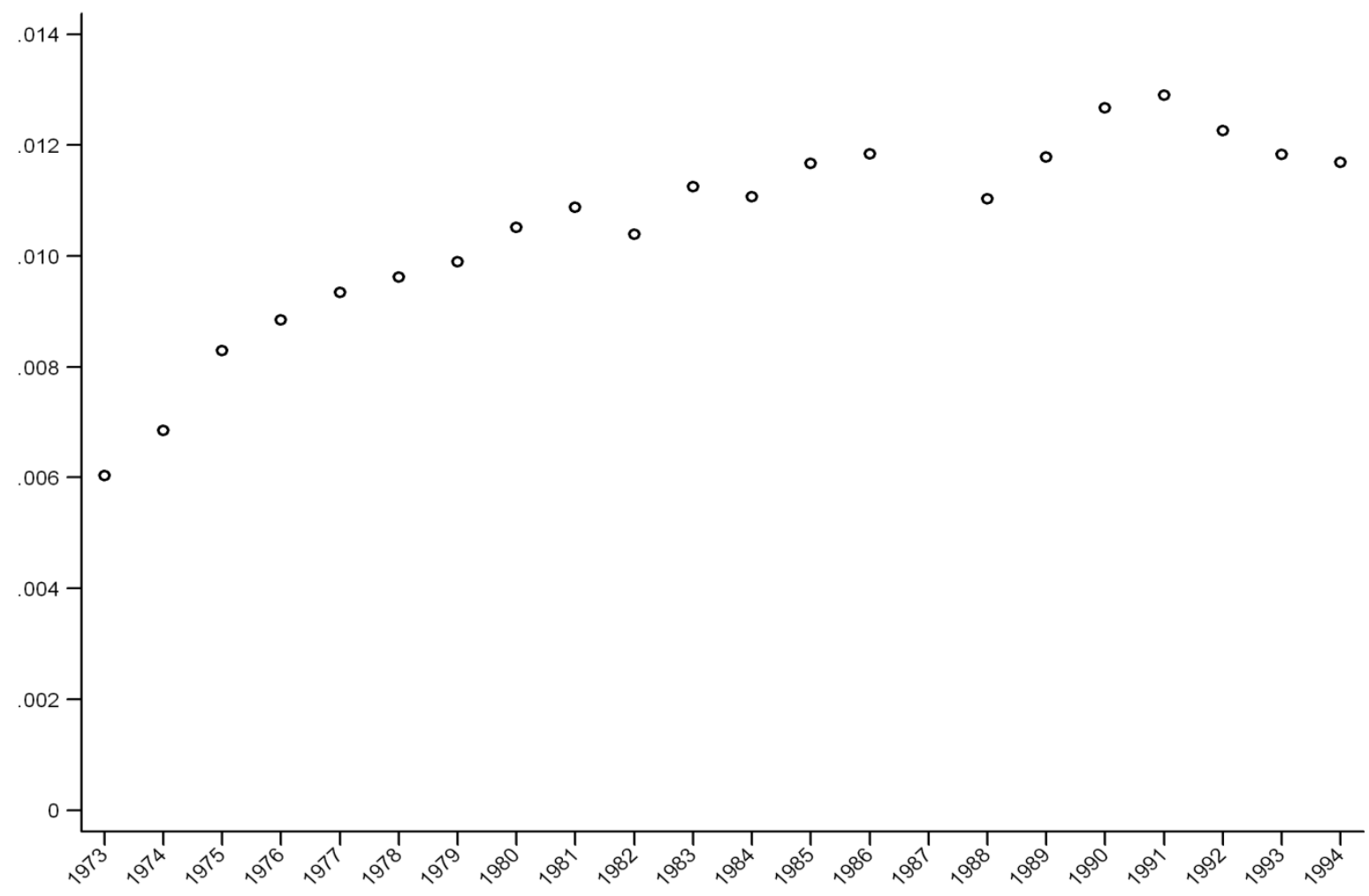

$\bar{\dagger}$ Author's calculations from statistics published by the U.S. Census Bureau from its Pollution Abatement Costs and Expenditures survey, Census of Manufactures, and Annual Survey of Manufactures.

23 